\title{
Reviewing the Safe Shipping of Lithium-Ion and Sodium-Ion Cells: A Materials Chemistry Perspective
}

\author{
Ashish Rudola $(\mathbb{D}$, Christopher J. Wright $\mathbb{D}$, and Jerry Barker $\mathbb{D}$
}

Faradion Limited, The Innovation Centre, 217 Portobello, Sheffield S1 4DP, UK

Correspondence should be addressed to Jerry Barker; jerry.barker@faradion.co.uk

Received 30 April 2021; Accepted 29 August 2021; Published 25 November 2021

Copyright (c) 2021 Ashish Rudola et al. Exclusive Licensee Beijing Institute of Technology Press. Distributed under a Creative Commons Attribution License (CC BY 4.0).

\begin{abstract}
High energy density lithium-ion (Li-ion) batteries are commonly used nowadays. Three decades' worth of intense research has led to a good understanding on several aspects of such batteries. But, the issue of their safe storage and transportation is still not widely understood from a materials chemistry perspective. Current international regulations require Li-ion cells to be shipped at $30 \%$ SOC (State of Charge) or lower. In this article, the reasons behind this requirement for shipping Li-ion batteries are firstly reviewed and then compared with those of the analogous and recently commercialized sodium-ion (Na-ion) batteries. For such alkali-ion batteries, the safest state from their active materials viewpoint is at $0 \mathrm{~V}$ or zero energy, and this should be their ideal state for storage/shipping. However, a "fully discharged" Li-ion cell used most commonly, composed of graphitebased anode on copper current collector, is not actually at $0 \mathrm{~V}$ at its rated $0 \%$ SOC, contrary to what one might expect-the detailed mechanism behind the reason for this, namely, copper dissolution, and how it negatively affects cycling performance and cell safety, will be summarized herein. It will be shown that $\mathrm{Na}$-ion cells, capable of using a lighter and cheaper aluminum current collector on the anode, can actually be safely discharged to $0 \mathrm{~V}$ (true $0 \%$ SOC) and beyond, even to reverse polarity (negative voltages). It is anticipated that this article spurs further research on the $0 \mathrm{~V}$ capability of Na-ion systems, with some suggestions for future studies provided.
\end{abstract}

\section{Introduction}

The modern lithium-ion (Li-ion) battery is now ubiquitous. By virtue of its high energy density, it has pervaded many sectors of modern day-to-day life as the de-facto battery choice therein, such as consumer electronics, personal mobility devices, or hybrid/fully electric vehicles [1]. As an example of the sheer scale of use of Li-ion batteries in the world today, the number of laptops and tablets shipped worldwide in 2020 was estimated at around 377 million units [2], while the number of mobile phones shipped just in the last quarter of 2020 was estimated at 374 million units [3]. This demand for Li-ion batteries requires them to be shipped worldwide in large quantities.

From a safety viewpoint, it is now well known that Li-ion batteries can pose major fire/explosion hazards if appropriate care is not taken during their storage, transportation, and also operation [4-6]. Due to such safety concerns, Liion batteries are officially classified as "Dangerous Goods" by national as well as international transport authorities, such as the UNECE (United Nations Economic Commission for Europe) or the IATA (International Air Transport Association) [7-9]. There are, thus, strict international regulations concerning the safe transport and storage of Li-ion batteries, with the latest regulations stipulating that the State of Charge (SOC) of a Li-ion battery should not exceed $30 \%$ during storage or shipping [7-9]. Such requirements make shipping Li-ion cells a costly affair $[4,8,10,11]$.

It should be stressed that the working principle of the $\mathrm{Li}$ ion battery is not inherently unsafe: it is the materials used in these batteries, such as the flammable liquid electrolytes, that can lead to major safety hazards $[6,12]$. As can be intuitively understood, the safest state for a rechargeable battery system will generally be at $0 \mathrm{~V}$, where there is no driving force at all between the positive electrode (cathode) and negative electrode (anode). However, for Li-ion batteries using a carbon-based anode, discharge down to $0 \mathrm{~V}$ is fraught with complications (to be discussed in detail in the next section). It should be stated that there are other types of $\mathrm{Li}$-ion batteries that can be discharged down to $0 \mathrm{~V}$, such as those using higher potential anodes such as lithium titanium oxide, for example, Toshiba's Super Charge ion Battery (SCiB) [13]. 
Evidently, the materials used in alkali-ion batteries can have a huge impact not only on their performance (such as on energy density or cycle life) but also on their safety.

On this point, consider the analogous sodium-ion (Naion) battery: this type of alkali-ion battery just requires a swap between the lithium-based materials used in Li-ion batteries with that of sodium-based materials, without any change in the working principle of the battery or methods to manufacture the battery [14]. In the last decade, there has been tremendous research focus on $\mathrm{Na}$-ion batteries due to a multitude of reasons such as their expected low costs on account of the much greater sodium resources in the earth relative to lithium resources, prospects for achieving fairly high energy densities together with long cycle life, good rate and temperature performance, fast charge capability, and importantly enhanced safety [15-17]. As a result, $\mathrm{Na}$-ion batteries have now been commercialized [11, 14, 18].

The purpose of this review article is to focus on one particular aspect of commercially available room temperature rechargeable alkali-ion batteries: the requirements of storing and shipping such batteries, from a basic materials chemistry point of view, for both $\mathrm{Li}$-ion and $\mathrm{Na}$-ion batteries. In doing so, we will firstly summarize the chemistry limitations of discharging Li-ion batteries to $0 \mathrm{~V}$ and also highlight what problems arise upon deep discharge to $0 \mathrm{~V}$ and beyond, to negative voltages. We will then touch on analogous data for $\mathrm{Na}$-ion batteries and present the case for why deep discharging Na-ion cells to $0 \mathrm{~V}$ does not negatively influence performance and why doing so is inherently very safe. By putting a spotlight on this practical issue of storing and transporting alkali-ion cells, we hope to further boost confidence in the Na-ion technology as a cost-effective complementary technology to its older cousin, the Li-ion battery.

\section{Discharging Li-Ion Batteries to 0 V: Issues and Risks}

The Li-ion battery chemistry is varied as different types of materials can be used in its cathode, anode, and electrolyte. But the Li-ion chemistry used most commonly currently and which is also the most energy dense, contains a graphite-based anode (either graphite being the sole active material or mixed with some alloy-forming material such as $\mathrm{Si}$ ), a lithium nickel-manganese-cobalt oxide or lithium nickel-cobalt-aluminum oxide cathode (abbreviated as NMC or NCA, respectively) and flammable liquid electrolytes using $\mathrm{LiPF}_{6}$ salt and carbonate-ester solvents such as ethylene carbonate (EC), dimethyl carbonate (DMC), or diethyl carbonate (DEC). Another commonly used Li-ion cathode utilises $\mathrm{LiFePO}_{4}$ (LFP): LFP//graphite Li-ion cells might have lower energy densities but have other benefits such as better rate performance or enhanced safety. The issue of deep discharging such NMC/NCA/LFP//graphite Li-ion batteries to $0 \mathrm{~V}$ stems not from the actual active materials in the cathode and anode but from the current collectors used as the substrate to form the cathode/anode. Specifically, aluminum current collectors are used for the cathode, but copper current collectors are used for the anode. It would be preferable for both cathode and anode to use $\mathrm{Al}$, as $\mathrm{Al}$ is not only much lighter than $\mathrm{Cu}$ but also cheaper [14, 19-21]. Unfortunately, Li alloys with Al to form $\mathrm{Li}_{\mathrm{x}} \mathrm{Al}$ at low potentials vs. $\mathrm{Li} / \mathrm{Li}^{+}$, thus requiring the need for $\mathrm{Cu}$ on the anode, as $\mathrm{Li}$ does not diffuse into $\mathrm{Cu}$ in appreciable quantities during normal operation of a rechargeable Liion cell [22]. While other materials could also be used as the anode current collector, $\mathrm{Cu}$ is by far the most commonly used currently. [23]

The use of $\mathrm{Cu}$ current collector on the anode is the chief reason why graphite-based Li-ion cells cannot be discharged down to $0 \mathrm{~V}$. To better understand this point, it might be useful to remember that a Li-ion cell's voltage at any point during the cell's cycling is simply the potential of the anode subtracted from the potential of the cathode. This is schematically explained in Figure 1(a) for a hypothetical alkaliion full cell, with the potentials referenced against the alkali metal's redox potential (for example, vs. $\mathrm{Li} / \mathrm{Li}^{+}$). It should be kept in mind that there are several factors influencing a full cell's output voltage, such as the reversible capacities of the anode and cathode and ratio of the masses of the active materials in the anode and cathode (both points dictate a full cell's anode:cathode capacity balance or the so-called N/P ratio), kinetics of the alkali-ion storage in anode/cathode, kinetics of the electrolyte, operating temperature, or cycling rate, to name just a few. For simplicity and relevance to the discussion herein, we can consider the case of commercial graphite Li-ion cells which have been appropriately balanced (N/P ratio slightly in excess of 1$)$. These Li-ion cells are capacity balanced in such a way that they are designed to be discharged down to $2-2.8 \mathrm{~V}$ (typically, depending on the manufacturer), and this full cell voltage is classified as $0 \%$ SOC or $100 \%$ DOD (Depth of Discharge) [24, 25]. However, these cells are obviously not at $0 \mathrm{~V}$ at this state, and they can be further discharged beyond $0 \%$ SOC, to voltages such as $1 \mathrm{~V}, 0 \mathrm{~V}$, or even $-1 \mathrm{~V}$ (these states are often referred to as "overdischarged states" in the literature) [26-29].

Returning to Figure 1(a), it can be seen that during discharge of a Li-ion cell, the anode's potential continuously increases. For Li-ion cells using graphite-based anodes on $\mathrm{Cu}$ current collectors, the issue arises when the anode's potential is allowed to rise to high potentials vs. $\mathrm{Li} / \mathrm{Li}^{+}$. It is known that $\mathrm{Cu}$ oxidizes at potentials above $3 \mathrm{~V}$ vs. $\mathrm{Li} / \mathrm{Li}^{+}$: the thermodynamic potentials (in aqueous media) of the $\mathrm{Cu} / \mathrm{Cu}^{2+}$ and $\mathrm{Cu} / \mathrm{Cu}^{+}$redox couples are $3.377 \mathrm{~V}$ vs. $\mathrm{Li} / \mathrm{Li}^{+}$ and $3.56 \mathrm{~V}$ vs. $\mathrm{Li} / \mathrm{Li}^{+}$, respectively. $\mathrm{Cu}$ dissolution is a known problem and is the reason why commercial graphite-based Li-ion cells are not discharged to $0 \mathrm{~V}$. When graphitebased Li-ion cells are overdischarged, the graphite anode's potential increases beyond $3 \mathrm{~V}$. For example, Kasnatscheew et al. show, using three-electrode NMC//graphite full cells (where a Li metal reference electrode can track the individual potentials of the cathode as well as the anode in the course of cycling, thus yielding potentials vs. $\left.\mathrm{Li} / \mathrm{Li}^{+}\right)$, that if such Li-ion cells are allowed to overdischarge (common causes for overdischarging Li-ion cells mentioned in the next section), the graphite anode's potential will reach $3.56 \mathrm{~V}$ vs. $\mathrm{Li} / \mathrm{Li}^{+}$(refer to Figure 1(b)) indicative of $\mathrm{Cu}$ current collector's oxidation [29]. Upon continued overdischarging, the graphite anode's potential stayed flat around $3.56 \mathrm{~V}$ vs. 


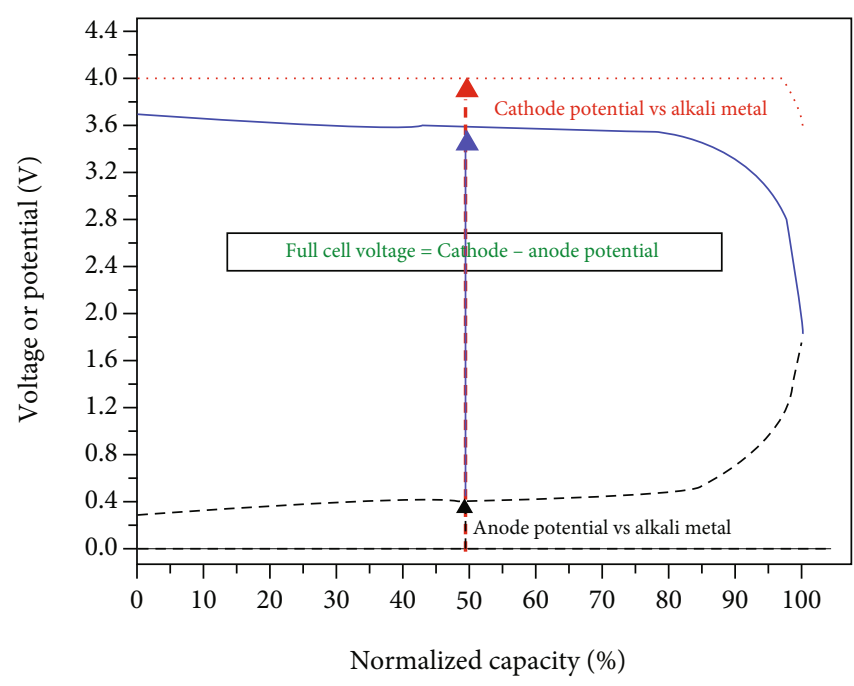

(a)

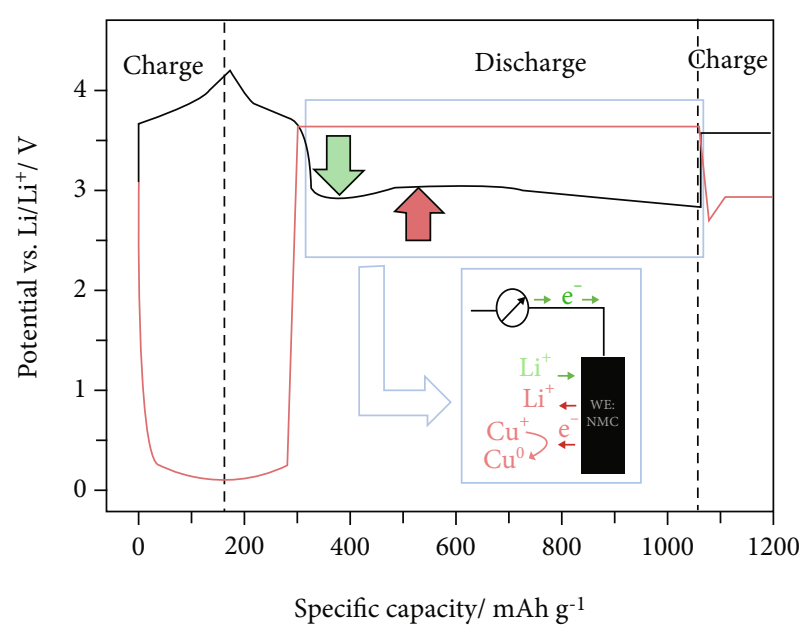

(b)

\footnotetext{
Cathode potential

- - - Anode potential

- Full cell voltage
}

FIgURE 1: Relationship of full cell voltage with the potentials of the cathode and anode. (a) Illustration of this relationship for a hypothetical alkali-ion full cell with the potentials referenced vs. the alkali metal's redox couple. Please note that $100 \%$ normalized capacity $=0 \%$ SOC. (b) Three-electrode cycling data of an NMC//graphite Li-ion cell which was overdischarged: data shows how the cathode and anode potentials vary in the course of overdischarging. (b) is reprinted from [29], Copyright (2017), with permission from Elsevier.

$\mathrm{Li} / \mathrm{Li}^{+}$even when the cell exceeded its design capacity by a factor of $\sim 6$. Simultaneously, the cathode potentials showed an unusual pseudo-plateau around $2.8-3 \mathrm{~V}$ vs. $\mathrm{Li} / \mathrm{Li}^{+}$. As noted by the authors, $\mathrm{Cu}$ deposition on the cathode occurred due to the fact that the cathode potential was lower than the anode potential in the overdischarged states; $\mathrm{Cu}$ deposition was identified by SEM-EDX (scanning electron microscopy-energy dispersive X-ray spectroscopy) [29].

While there might be some uncertainty regarding whether $\mathrm{Cu}$ oxidizes as $\mathrm{Cu}^{+}$or $\mathrm{Cu}^{2+}$, results from several studies indicate that the preferred oxidation of the copper current collector in typical nonaqueous $\mathrm{Li}$-ion electrolytes appears to proceed via the $\mathrm{Cu} / \mathrm{Cu}^{+}$redox couple (this cannot, however, be stated definitively currently due to conflicting reports in the literature), and that $\mathrm{Cu}$ deposition onto the cathode can be metallic in nature as well as $\mathrm{Cu}$ compounds such as $\mathrm{Cu}_{2} \mathrm{O}$ or $\mathrm{Cu}(\mathrm{OH})_{2}[26,29-32]$. There are numerous examples in the literature on the pernicious effects of overdischarging commercial Li-ion cells. As an illustration, Flügel et al. showed that overdischarged commercial 18650 -type $1.5 \mathrm{Ah} \mathrm{Li}$-ion cells when held at $0 \mathrm{~V}$ for $430 \mathrm{~h}$ ( 18 days), exhibited visible holes in the $\mathrm{Cu}$ current collector brought about by $\mathrm{Cu}$ dissolution (refer to Figure 2(a)) [33]. The consequences for even small amounts of $\mathrm{Cu}$ dissolution are profound for a $\mathrm{Li}$-ion cell. This is because it is known that $\mathrm{Cu}$ dissolution from the graphite-anode current collector could weaken the adhesion of the graphite anode's coating, and that the deposited $\mathrm{Cu}$ on the cathode (as either $\mathrm{Cu}$ compounds or metallic $\mathrm{Cu}$ ) blocks that portion of the cathode which it covers, effectively limiting the passage of $\mathrm{Li}^{-}$ ions between the electrodes, reducing cell capacity [32]. As a quantification of the impact of overdischarging of Li-ion cells to $0 \mathrm{~V}$, refer to data from Hendricks et al. shown in Figure 2(b) [32]. The authors of this study showed that $52 \mathrm{Ah}$ commercial Li-ion cells, when overdischarged to $0 \mathrm{~V}$ just one time, lost $\sim 10 \%$ of their capacity in 40 normally discharged cycles (the control samples, which were not overdischarged, showed no capacity fade in 40 cycles) [32]. In their study, Hendricks et al. did not see metallic $\mathrm{Cu}$ on the cathode (they observed $\mathrm{Cu}^{+}$and $\mathrm{Cu}^{2+}$ compounds)-the situation can be significantly worse, if not catastrophic, if metallic $\mathrm{Cu}$ precipitates on the cathode as detailed below.

From Figure 1, it can be seen that towards the tail-end of "regular discharge" of an appropriately balanced commercial Li-ion cell, the cathode and anode potentials are generally undergoing rapid decrease and rapid increase, respectively. Because of this, it is very easy and indeed fast for a Li-ion cell's voltage to slip from the rated $0 \%$ SOC to negative voltages (below $0 \mathrm{~V}$ ). It should be understood that the nature of full cell balancing as designed by a cell manufacturer would largely dictate how rapid this voltage slippage process would be and that this might vary between different cell manufacturers even for the same Li-ion chemistry. In these extreme overdischarged states, metallic $\mathrm{Cu}$ can easily be deposited on the cathode, as presented in Figures 3(a) and 3(b), with data from Langner et al. [28] and Ma et al. [34], respectively. Figure 3(a) displays metallic $\mathrm{Cu}$ plating on the cathode of a $20 \mathrm{Ah} \mathrm{Li}$-ion pouch cell, which was made to discharge up to $31.5 \mathrm{Ah}$ (the full cell voltage dropped as low as around $-2 \mathrm{~V})$. Under such conditions, Langner et al. reported extensive metallic $\mathrm{Cu}$ plating on the cathode, along with white spots belonging to the breakdown of the polyolefinic 


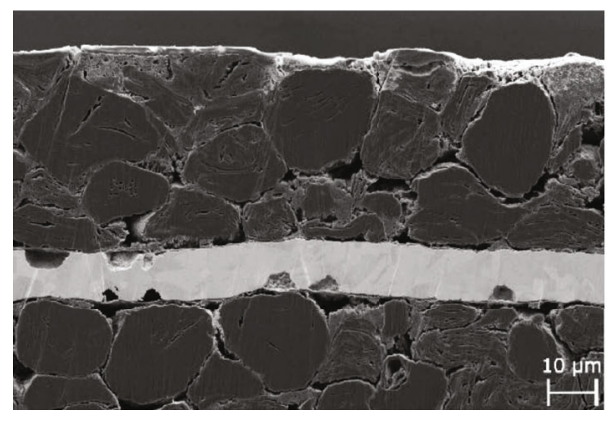

(a)

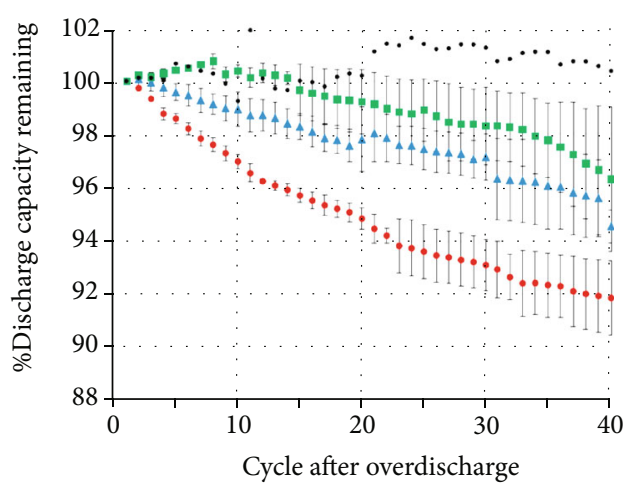

(b)

$\begin{array}{ll}\text { 0 V Mean } & -0.5 \mathrm{~V} \text { Mean } \\ 0.25 \mathrm{~V} \text { Mean } & \text { - Control sample }\end{array}$

FIGURE 2: Negative effects on graphite-based Li-ion cells when overdischarged to $0 \mathrm{~V}$. (a) Cross-section SEM image of a graphite anode harvested from an 18650-type commercial Li-ion cell which was held at $0 \mathrm{~V}$ for $430 \mathrm{~h}$ : visible holes on the Cu current collector can be clearly seen. (a) reproduced with permission from [33]. Copyright (2020) John Wiley and Sons. (b) Capacity retention of 52 Ah commercial NCA//graphite Li-ion cells (cycled between 2.5 and $4.1 \mathrm{~V}$ ) after a single overdischarge event where the cells were held at $0.5 \mathrm{~V}, 0.25 \mathrm{~V}$, or $0 \mathrm{~V}$ for nine months. (b) reproduced under the terms of CC BY 4.0 from [32].

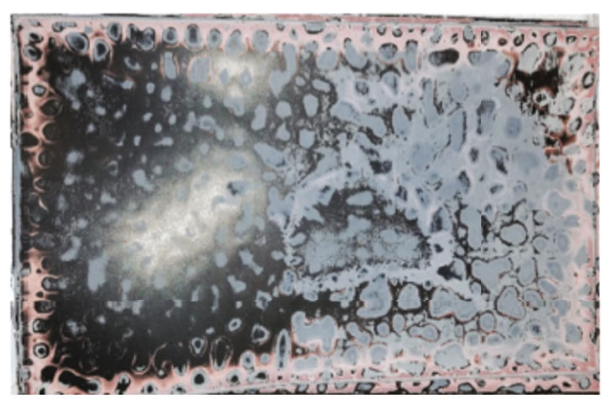

(a)
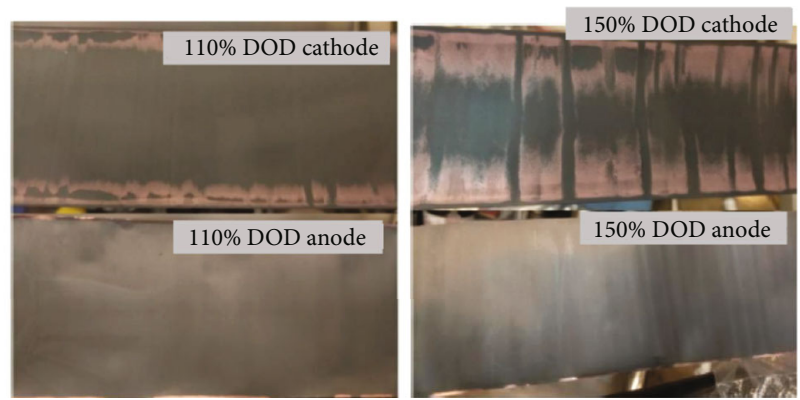

(b)

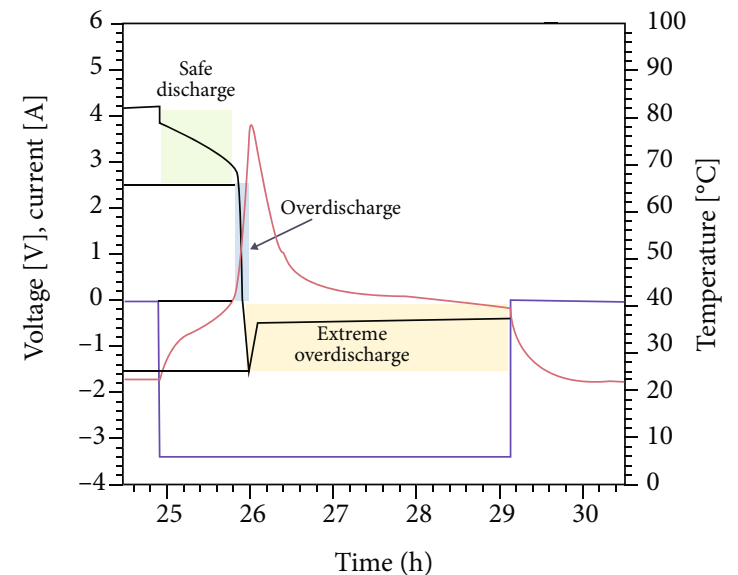

(c)

$$
\begin{aligned}
& \text { — Voltage } \\
& \text { — Current } \\
& \text { — Temperature }
\end{aligned}
$$

FIGURE 3: The effects of overdischarging graphite-based Li-ion cells to negative voltages. (a) Image of the cathode retrieved from a $20 \mathrm{Ah}$ rated $\mathrm{NMC//graphite} \mathrm{Li-ion} \mathrm{pouch} \mathrm{cell} \mathrm{which} \mathrm{was} \mathrm{overdischarged} \mathrm{till} \mathrm{a} \mathrm{capacity} \mathrm{of} 31.5 \mathrm{Ah}$ resulting in full cell voltages as low as $-2 \mathrm{~V}$ : $\mathrm{Cu}$ deposits can be clearly seen. (a) reproduced under the terms of a Creative Commons Attribution 4.0 International License from [28]. (b) Images of the cathode and anode retrieved from 18650-type NMC//graphite Li-ion cells which were overdischarged to negative voltages, clearly showing metallic $\mathrm{Cu}$ deposits on the cathode. (b) reprinted with permission from [34]. Copyright (2020) American Chemical Society. (c) A dangerous spike in the temperature of an NCA//graphite Li-ion cell when overdischarged beyond its rated $0 \%$ SOC $(2.5 \mathrm{~V})$ at a $1 \mathrm{C}$ discharge rate. (c) reproduced under the terms of CC BY-NC-ND 4.0 from [35]. 
separator typically used in commercial Li-ion batteries [28]. Similarly, in Figure 3(b), Ma et al. reported that 2.5 Ah 18650-type NMC//graphite Li-ion cells, when overdischarged to $110 \%$ or $150 \%$ DOD (corresponding to full cell voltages of $-1.12 \mathrm{~V}$ and approximately $-0.3 \mathrm{~V}$ ), showed significant metallic $\mathrm{Cu}$ deposition on the cathode and that the extent of metallic $\mathrm{Cu}$ deposition increased as the extent of overdischarge increased [34]. It might be worth mentioning that as overdischarging is allowed to continue, studies have reported that the voltage of $\mathrm{Li}$-ion cells first decrease to a minimum (such as -1 or $-2 \mathrm{~V}$ ) and then increase, gradually tending towards $0 \mathrm{~V}$-such an increase in voltage is believed to arise due to internal shorting in the cell caused by the growth of metallic dendritic $\mathrm{Cu}$ on the cathode, which can pierce through the separator and hence cause localised contacts between the cathode and the anode [28, 30, 34-36]. Extreme overdischarging can have serious consequences as the internal microstructure of the battery is compromised: issues such as internal shorting due to growth of metallic dendritic $\mathrm{Cu}$ and decrease in the mechanical integrity of the separator, reduced porosities in the cathode and blockage of electrochemical active sites on the cathode can not only result in rapid capacity loss but also pose serious thermal hazards $[32,34,35]$. For example, Fear et al. showed that a Li-ion cell's temperature can rapidly increase when overdischarged at $1 \mathrm{C}$ cycling rate (discharge in $1 \mathrm{~h}$ ) - as shown in Figure 3(c), a $3.35 \mathrm{Ah}$ 18650-type Liion cell's temperature rose from $21^{\circ} \mathrm{C}$ at the beginning of discharge to $65^{\circ} \mathrm{C}$ at $0 \mathrm{~V}$ and reached a peak temperature of $79^{\circ} \mathrm{C}$ shortly after reaching $0 \mathrm{~V}$ in the course of overdischarging the cell [35]. While such temperatures might not necessarily induce thermal runaway, as detailed previously, irreversible damage to the cell would already have occurred by this point.

\section{Causes of Overdischarge in Commercial Li-Ion Cells}

The discussions presented above highlight the need to prevent overdischarging of Li-ion cells, but despite a battery manufacturer's best attempts to produce consistent cells without manufacturing defects, overdischarging of Li-ion cells might still occur in the course of their operation by several mechanisms. Perhaps the most common cause might be when Li-ion cells are connected in series to form strings of cells, as occurs in most high voltage Li-ion battery packs used for applications such as different types of electric vehicles or stationary energy storage. As each cell in a series string would experience the same amount of current flow, if the string has even one underperforming cell with lower capacity compared with its sister cells in the string, that underperforming cell might have the potential to experience overdischarge or overcharge conditions; healthy cells with their rated capacity would not experience this $[31,37,38]$. There are several studies in the literature that discuss the best techniques or models to quantify the likelihood of premature cell failure caused by cell-by-cell variations [39-42]. As an illustration, a recent study by Xie et al. studied cell-by-cell variations of 80 commercially available $3 \mathrm{Ah}$ NCA//graphite 18650-type Li-ion cells from Panasonic
[39]. They showed that the standard deviation (SD) in delivered capacities from these cells was $0.63 \%$ in the initial cycles, with a capacity swing between the best and the worst cell being $0.1087 \mathrm{Ah}$. Furthermore, the authors also connected the 80 cells in series to form a string and controlled the cycling of the series string by just current and duration (thus, capacity for each cell was the same) and measured the voltage response. They showed that the 80 -cell series string could show as much as $2.14 \% \mathrm{SD}$ in the voltage at the end of the discharge with a voltage swing as high as $0.3 \mathrm{~V}$ between the best and the worst performing cell [39]. While not a concern in the initial cycles, the effects of such cell-by-cell variations multiply with continued cycling. For example, Preger et al. observed that the cycle life to $20 \%$ capacity fade for three Panasonic 18650-type NCA//graphite Li-ion cells varied from $\sim 430$ cycles to $\sim 535$ cycles (SD $\sim 53$ ) at $1 \mathrm{C}$ discharge from $100 \%$ SOC to the rated 0\% SOC: in contrast, when at $5 \%$ capacity fade (around cycles $90-100$ for the different cells), these cells demonstrated significantly lower SD $\sim 6$ [41]. Similar conclusions were demonstrated by Harris et al. utilising $24 \mathrm{LiCoO}_{2} / /$ graphite Li-ion pouch cells with a rated capacity of $4.4 \mathrm{Ah}$ using an accelerated aging study with 10C discharge: these 24 cells demonstrated almost identical capacity fade after 100 cycles, but their cycle number to $20 \%$ capacity fade varied widely (from 255 cycles to 560 cycles with an SD of 94), with four pouch cells not having reached $20 \%$ capacity fade by cycle 560 [42]. It can thus be appreciated that for Li-ion cells connected in series, chances of overdischarge of the underperforming cells could start becoming statistically significant towards the second half of their expected cycle lives.

Once a cell has experienced overdischarge, its performance would subsequently be compromised and thus induce greater load on the healthy sister cells which might now be forced to supply the missing capacity, thereby increasing the likelihood of their failure in turn. To mitigate this, in Li-ion packs, it is standard-practice to use a Battery Management System (BMS). BMS systems vary widely in their abilities to balance cells and handle underperforming cells - the more technologically advanced BMS systems tend to cost more, thus increasing the price of commercial packs [37]. BMS systems rely on monitoring the SOC of individual cells or assemblies of cells such as modules or submodules. There have been many studies on the best techniques to measure the SOC of Li-ion cells, as the cycling profiles of Li-ion cells used to estimate the SOC can vary widely based on different Li-ion chemistries, and thus, it is not a straightforward task [43-45]. However, if the BMS system fails due to any reason, the likelihood of Li-ion cells overdischarging would also increase.

Another route whereby overdischarging of Li-ion cells might occur is from the self-discharge of Li-ion cells, especially when the cells are stored for long periods of time. The likelihood of overdischarge due to self-discharge for a particular Li-ion cell is quite dependent on the temperature as higher temperatures significantly increase the selfdischarge rates [46-49]. Another variable that affects selfdischarge rates is the SOC of the Li-ion cells-the selfdischarge rates are higher at high SOCs and are actually 
quite low at low SOCs [48, 50, 51]. For instance, Zimmermann shows that at $20^{\circ} \mathrm{C}, \mathrm{LiNi}_{\mathrm{x}} \mathrm{Co}_{1-\mathrm{x}} \mathrm{O}_{2} / /$ graphite $\mathrm{Li}$-ion $40 \mathrm{Ah}$ cells exhibited self-discharge current values between $\sim \mathrm{C} / 20,000$ and $\sim \mathrm{C} / 14,000$ at $3.30 \mathrm{~V}(\sim 15 \%$ SOC for typical $\mathrm{LiNi}_{\mathrm{x}} \mathrm{Co}_{1-\mathrm{x}} \mathrm{O}_{2} / /$ graphite cells) [47] during long-term storage, depending on the method of self-discharge rate estimation [51]. The mean value of the self-discharge rate $(\sim \mathrm{C} / 17,000)$ would indicate that the cell might self-discharge from $15 \%$ SOC to $0 \%$ SOC in $\sim 3.5$ months, and thus, overdischarge beyond this timeframe. However, caution is advised when generalizing such results to other kinds of Li-ion cells as it is also known that different Li-ion chemistries and/or types can exhibit different rates of self-discharge $[47,51]$. For example, Redondo-Iglesias et al. observed that $\mathrm{NMC//graphite} \mathrm{Li-ion} \mathrm{polymer} \mathrm{cells} \mathrm{demonstrated} \mathrm{neg-}$ ligible self-discharge rates at $30 \% \mathrm{SOC}$ at $30^{\circ} \mathrm{C}[48,52,53]$. In real-world settings, effects of self-discharge might become relevant for applications such as back-up energy storage or in military applications, where the batteries might not be used for several years. During this time, apart from self-discharge, the cells might have small load requirements of the BMS and/or might even have parasitic loads. Thus, if not managed correctly, the cells might slip in time to overdischarge conditions, especially at elevated temperatures $[23,32,54]$. This situation might also occur in electric vehicles that are parked at low SOCs for long durations especially at high temperatures above $40^{\circ} \mathrm{C}$-they can actually overdischarge during this time (and thus significantly affect lifetime of the battery as already outlined in the previous section) [31].

\section{Shipping Constraints for Li-Ion Cells}

As mentioned previously, the current international regulations stipulate that the Li-ion cells should have a maximum SOC of $30 \%$ during shipping. It is now well understood that as the SOC of a Li-ion cell increases, so does its thermal instability. For instance, Doughty and Routh showed that the peak thermal instability of a Li-ion 18650-type cell rapidly increased with its SOC, as measured by Accelerating Rate Calorimetry (ARC) - as also depicted in Figure 4(a), the peak self-heating rate of the cell at $4.3 \mathrm{~V}$ was almost double than that at $3.8 \mathrm{~V}$, along with slightly lower onset temperature of self-heating (the higher the onset temperature for self-heating, the more thermally stable the cell) [5]. While this data was obtained using the less commonly utilised $\mathrm{LiCoO}_{2}$ cathode, the principles would be translatable to any alkali-ion system. As an example, recent data from Börner et al. on $\mathrm{LiNi}_{0.5} \mathrm{Mn}_{0.3} \mathrm{Co}_{0.2} \mathrm{O}_{2}$ (NMC532)//graphite 2.2 Ah 18650-type Li-ion cells provided some valuable insights on the thermal stability of commercial Li-ion cells common currently [55]. Figure 4(b) presents their ARC data on fresh Li-ion cells that were charged to either $0 \% \mathrm{SOC}$, $50 \%$ SOC, or $100 \%$ SOC, along with corresponding data for these cells cycled to $20 \%$ capacity fade at $20^{\circ} \mathrm{C}$ (thus, at $80 \% \mathrm{SOH}$ or State of Health). The authors defined $T_{\text {onset }}=$ $0.02 \mathrm{~K} / \mathrm{min}$, as the onset temperature for self-sustaining exothermic reactions, while $T_{\mathrm{TR}}=10 \mathrm{~K} / \mathrm{min}$ was defined as the onset of thermal runaway. Thermal runaway is the worst- case scenario when it comes to battery safety and involves a situation where the cell's temperature is allowed to rise to such a degree that no easily implementable form of intervention, such as common cooling systems for Li-ion battery packs, would prevent further rise in temperatures-thermal runaway situations in commercial-scale Li-ion cells generally result in catastrophic fires or explosions, often scaling with the size of the cell $[5,6]$. With this in mind, it can be seen from Figure 4(b) that as the SOC of the Li-ion cell increased, the easier it was for the cell to reach $T_{\mathrm{TR}}$ : in fact, for the $0 \%$ SOC Li-ion cell, $T_{\mathrm{TR}}$ was avoided completely, at least up to $300^{\circ} \mathrm{C}$. Furthermore, the $T_{\text {onset }}$ temperature was higher as the SOC of the cell decreased [55]. Similar results were seen by Ribière et al., for $\mathrm{LiMn}_{2} \mathrm{O}_{4}$ (a much safer Liion cathode than NMC) [5]//graphite Li-ion 2.9 Ah pouch cells utilising oxygen consumption calorimetry: as shown in Figure 4(c), the 0\% SOC cell demonstrated a heat release rate (HRR) of $0.22 \mathrm{MW} / \mathrm{m}^{2}$, significantly lower than that of the $50 \%$ SOC cell $\left(\mathrm{HRR}=1.03 \mathrm{MW} / \mathrm{m}^{2}\right)$ and $100 \%$ SOC cell $\left(\mathrm{HRR}=1.7 \mathrm{MW} / \mathrm{m}^{2}\right)$, the latter of which was almost comparable to that of highly flammable gasoline [56].

The safety implication of the above was one of the main reasons why international regulations for shipping were modified in 2016: prior to 2016, it was common for Li-ion cells to be shipped at 50\% SOC [57]. The above data indicates that the requirement of shipping or storing Li-ion cells at 30\% SOC might still not be very safe-for Li-ion cells, it is clear that their safest state is at $0 \%$ SOC. However, shipping carbon anode-based Li-ion cells at $0 \%$ SOC is not actually feasible as these Li-ion cells can undergo self-discharge at low SOCs and slip to overdischarge conditions over long time durations especially at elevated temperatures, as previously mentioned.

\section{Uniqueness of the Na-Ion Chemistry: Discharge to $0 \mathrm{~V}$}

The Na-ion battery chemistry allows the use of $\mathrm{Al}$ current collector on the anode as Na-Al binary alloys are not known to date, where $\mathrm{Na}$ is present in $\mathrm{Al}$ in appreciable quantities to affect battery performance [58]. Thus, use of $\mathrm{Al}$ on the anode conveniently circumvents all issues seen with overdischarging graphite-based Li-ion cells as detailed in the previous sections. As shown in Figure 5(a), a three-electrode Na-ion cell utilising a mixed-phase $\mathrm{Na}_{\mathrm{a}} \mathrm{Ni}_{(1-\mathrm{x}-\mathrm{y}-\mathrm{z})} \mathrm{Mn}_{\mathrm{x}} \mathrm{Mg}_{\mathrm{y}} \mathrm{Ti}_{\mathrm{z}} \mathrm{O}_{2}$ $(0<a, x, y, z \leq 1)$ cathode, hard carbon anode, and liquid electrolyte composed of $\mathrm{NaPF}_{6}$ salt in carbonate-ester solvents can be discharged down to $0 \mathrm{~V}$ without any issues such as $\mathrm{Al}$ dissolution, as gauged from the smooth cycling profiles $[14,18,59]$. It can be seen that at $0 \mathrm{~V}$ for the full cell, the anode potential is around $2.7 \mathrm{~V}$ vs. $\mathrm{Na} / \mathrm{Na}^{+}$, a very safe value keeping in mind the electrochemical stabilities of carbonateester solvents [60]. In terms of cycling stability, Figures 5(b) and 5(c) show long-term cycling of a Na-ion cell between 4.3 and $0 \mathrm{~V}$, where the cell was potentiostatically held at $0 \mathrm{~V}$ for $48 \mathrm{~h}$ at the end of each discharge [18]. It can be seen that the cell's cycling stability was not compromised upon deep discharge to $0 \mathrm{~V}$. Effects of long-term shorting of Faradion's $\mathrm{Na}$-ion cells at $0 \mathrm{~V}$ have been investigated as well with time 


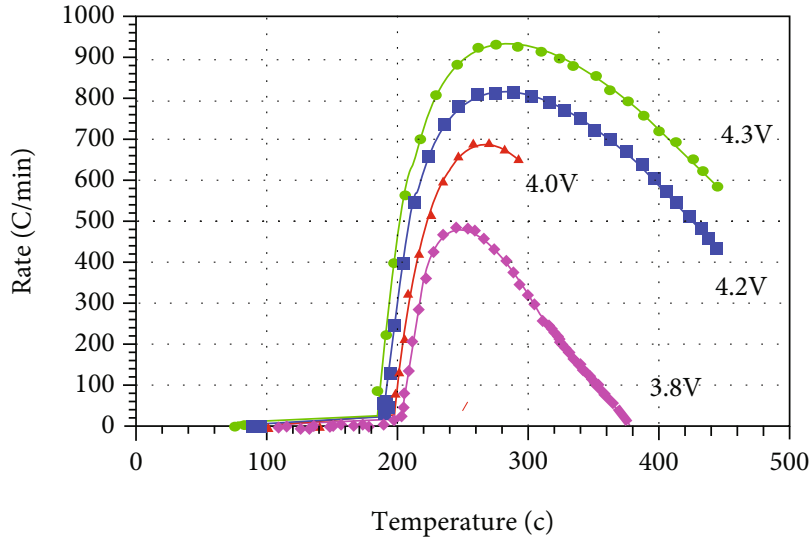

(a)

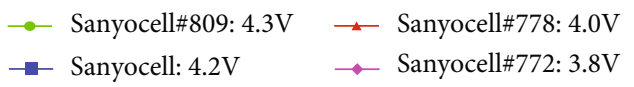

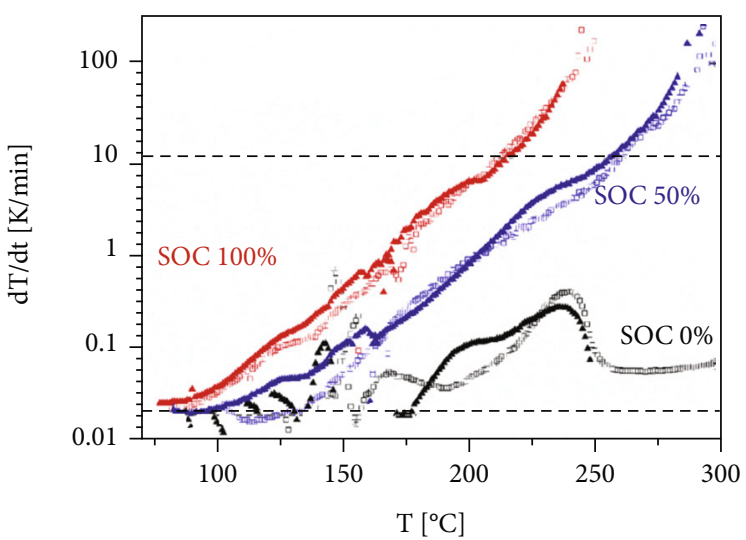

(b)

- Reference, $100 \% \mathrm{SOH}$

- $20^{\circ} \mathrm{C}, 80 \% \mathrm{SOH}$

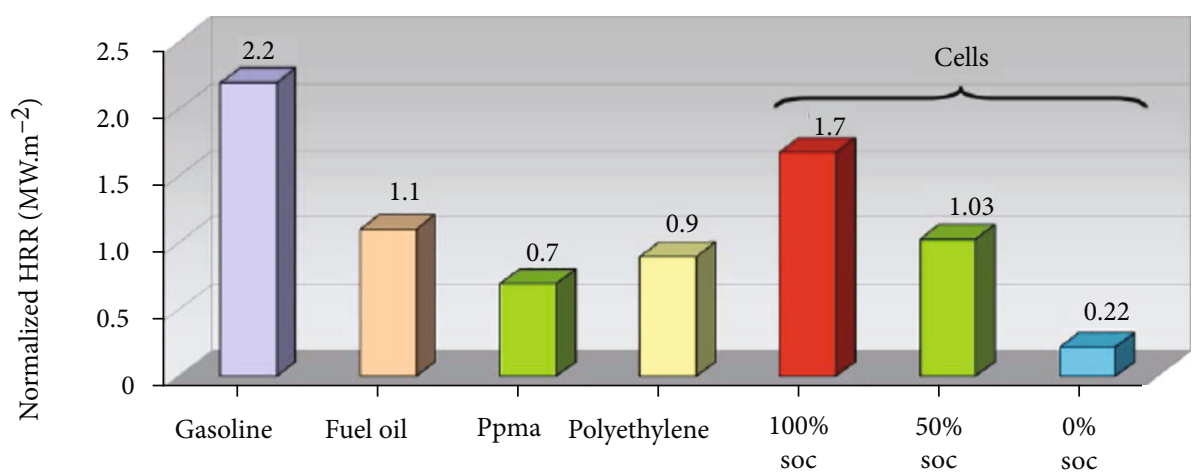

(c)

FIGURE 4: Relationship between the thermal stability of a Li-ion cell and its SOC. (a) ARC data on $\mathrm{LiCoO}_{2} / /$ graphite 18650 -type Li-ion cell showing the increasing thermal instability at higher voltages (higher SOC). (a) reproduced from [5], () The Electrochemical Society. Reproduced by permission of IOP Publishing. All rights reserved. Please note that the unit for temperature is ${ }^{\circ} \mathrm{C}$. (b) Heating rates (dT/dt) measured by ARC on NMC532//graphite 18650-type Li-ion cells on either fresh cells (hollow symbols) or those cycled to 80\% $\mathrm{SOH}$ (filled symbols) at different SOCs. (b) reprinted from [55], Copyright (2017), with permission from Elsevier. (c) Comparisons between the normalized heat release rate (HRR) of $\mathrm{LiMn}_{2} \mathrm{O}_{4} /$ graphite Li-ion pouch cells at different SOCs, with that of some combustible materials. (c) reproduced from [56], Copyright (2012), with permission from Royal Society of Chemistry.

durations such as three, six, or twelve months, with little impact on long-term cycling stability. As an example, refer to Figure 5(d), which compares the cycling stabilities of two Na-ion cells: one cell was physically shorted for six months at $0 \mathrm{~V}$, while the other was the baseline cell which did not undergo this $0 \mathrm{~V}$ short [14]. As can be seen, the cycling stability for the $0 \mathrm{~V}$ shorted cell over six months was found to be identical with that of the baseline cell.

From the above, it should be apparent that discharging $\mathrm{Na}$-ion cells to $0 \mathrm{~V}$ is not an abnormal event for Na-ion systems. Indeed, the temperature response of a $\mathrm{Na}$-ion cell further proves this. Figure 5(e) presents $1 \mathrm{C}$ discharge of a $12 \mathrm{Ah}$ $\mathrm{Na}$-ion pouch cell, from $100 \%$ SOC to $0 \mathrm{~V}$. At the start of the experiment, the pouch cell's temperature, as measured by a thermocouple attached on the cell's surface located in the middle of one of its faces, was $17.8^{\circ} \mathrm{C}$. In the course of discharge, the cell's temperature gradually increased, reaching a maximum value of $27.8^{\circ} \mathrm{C}$. Such a temperature increase of just $10^{\circ} \mathrm{C}$ can be contrasted with that of Li-ion cells, whose example was shown in Figure 3(c): for their 3.35 Ah Li-ion cell, Fear et al. reported a temperature rise of $44^{\circ} \mathrm{C}$ from the start of $1 \mathrm{C}$ discharge to $0 \mathrm{~V}$.

\section{Overdischarging Na-Ion Cells below $0 \mathrm{~V}$}

As mentioned previously, in alkali-ion cells connected in series, it is possible that underperforming cells might be forced to overdischarge. For Na-ion, deep discharge down to $0 \mathrm{~V}$ is not an issue at all. However, it is still possible, in the event of extreme imbalances between cells in a series string of Na-ion cells, BMS malfunction, or cell manufacturing defects, that a Na-ion cell might be "overdischarged" below $0 \mathrm{~V}$, to negative voltages. Note here that we can now define the term "overdischarge" differently between the two types of alkali-ion batteries: for the Na-ion case, "overdischarge" should mean discharge below $0 \mathrm{~V}$ (to negative 


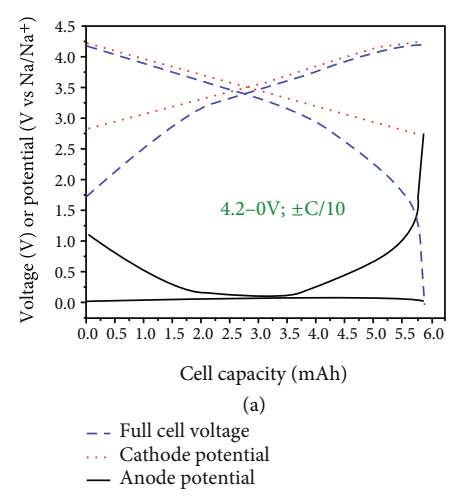

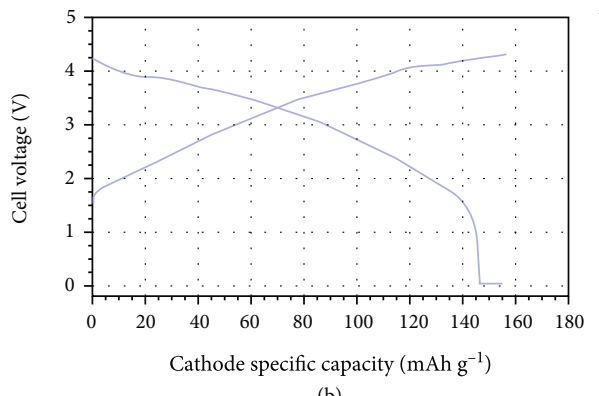

(b)

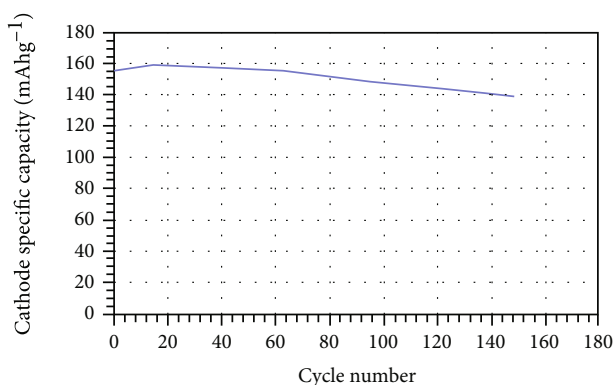

(c)

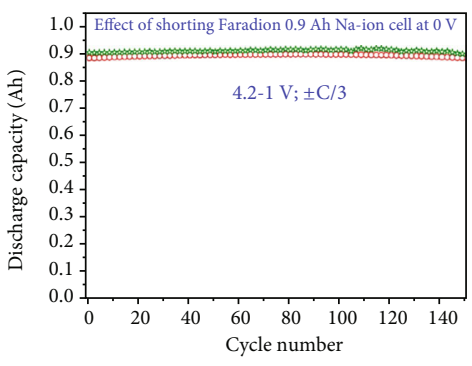

(d)

O Baseline cell: Not shorte 合 Six months short at $0 \mathrm{~V}$

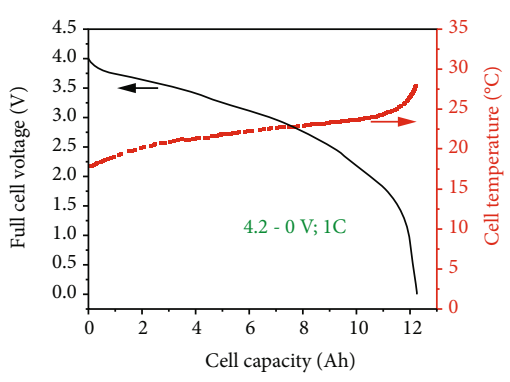

(e)

Figure 5: Effect of deep discharging Na-ion cells down to $0 \mathrm{~V}$. (a) Cycling of a three-electrode Na-ion cell between 4.2 and $0 \mathrm{~V}$ at $\pm \mathrm{C} / 10$ at $30^{\circ} \mathrm{C}$, showing no adverse reactions occurring on the anode or the cathode in the course of deep discharge to $0 \mathrm{~V}$. (b, c) Cycling profile and long-term cycling stability of a Na-ion cell cycled from 4.3 to $0 \mathrm{~V}$ at $\pm \mathrm{C} / 5$ at $30^{\circ} \mathrm{C}$; at the end of each cycle, the cell was potentiostatically held at $0 \mathrm{~V}$ for $48 \mathrm{~h}$. (b, c) reproduced with permission from [18]. Copyright (2018) John Wiley and Sons. (d) Cycling stabilities of two Na-ion cells at $4.2-1 \mathrm{~V}$ at $\pm \mathrm{C} / 3$ at $30^{\circ} \mathrm{C}$ : one cell was shorted for six months at $0 \mathrm{~V}$, while the other cell did not undergo this shorting procedure. (d) reproduced from [14] with permission from the Royal Society of Chemistry. (e) Cycling profile and temperature variation of a $12 \mathrm{Ah}$ Na-ion cell discharged at $1 \mathrm{C}$ from $4.2 \mathrm{~V}$ down to $0 \mathrm{~V}$ at room temperature, showing a temperature rise of just $10^{\circ} \mathrm{C}$.

voltages), but the meaning of "overdischarge" for graphitebased Li-ion cells is as conventionally used in the literature (discharge to below the rated 0\% SOC). If this event occurs, it is not yet known how a Na-ion cell might respond. To take the first steps towards addressing this issue, Figure 6(a) presents three-electrode cycling curves of a $5.5 \mathrm{mAh}$ nominal capacity Na-ion pouch cell that was discharged at $\mathrm{C} / 2$ cycling rate from $100 \%$ SOC. This cell delivered its nominal capacity down to $0 \mathrm{~V}$. To simulate overdischarge conditions, the cell was allowed to discharge to $\sim 2.5$ times its nominal capacity. As can be seen, beyond $0 \mathrm{~V}$, the anode potential steadily kept increasing, before reaching very high potentials in excess of $5.2 \mathrm{~V}$ vs. $\mathrm{Na} / \mathrm{Na}^{+}$: such potentials are well beyond the oxidation stability limits of carbonate-ester electrolytes, and it is no surprise that the anode's potential stayed at such high values upon continued discharge due to continuous electrolyte decomposition [14, 60]. Simultaneously, the cathode potential kept decreasing steadily, with notable disturbances in its cycling profile. It is likely that oxidized electrolyte species, generated at the high potential anode, might have migrated to the cathode and caused such disturbances; however, further studies need to be conducted to understand these observations. Figures $6(\mathrm{~b})$ and $6(\mathrm{c})$ show the pictures of the anode and cathode, respectively, harvested from the cell after this overdischarge experiment. There were no visible decomposition products on the anode or the cathode (the picture was taken immediately after cell disassembly and neither anode nor cathode was washed with any solvent). Further studies, particularly utilising SEMEDX and other surface-sensitive characterisation techniques such as X-ray Photoelectron Spectroscopy (XPS), might provide useful information about the electrolyte decomposition species on the anode and cathode.

It should be stated that these are just the preliminary experiments in overdischarging Na-ion cells below $0 \mathrm{~V}-$ to the best of our knowledge, no other published study to date has investigated overdischarging of Na-ion cells below $0 \mathrm{~V}$. Further studies would be required to accurately estimate the extent to which overdischarging $\mathrm{Na}$-ion cells below $0 \mathrm{~V}$ is harmful to the cell. One obvious drawback is that overdischarging $\mathrm{Na}$-ion cells over long durations below $0 \mathrm{~V}$ might cause excessive electrolyte oxidation on the anode side, potentially resulting in significant gas generation which might negatively affect performance and also safety. It was shown recently that Na-ion chemistry can benefit significantly from utilising the thermally and oxidatively stable carbonate-ester solvent, propylene carbonate (PC), an option that is not ideal for graphite-based Li-ion cells as PC tends to exfoliate graphite's graphene layers [14]. Since PC-dominant electrolytes are quite thermally safe and some can even be nonflammable, it will need to be ascertained whether excessive gas generation by long overdischarging 


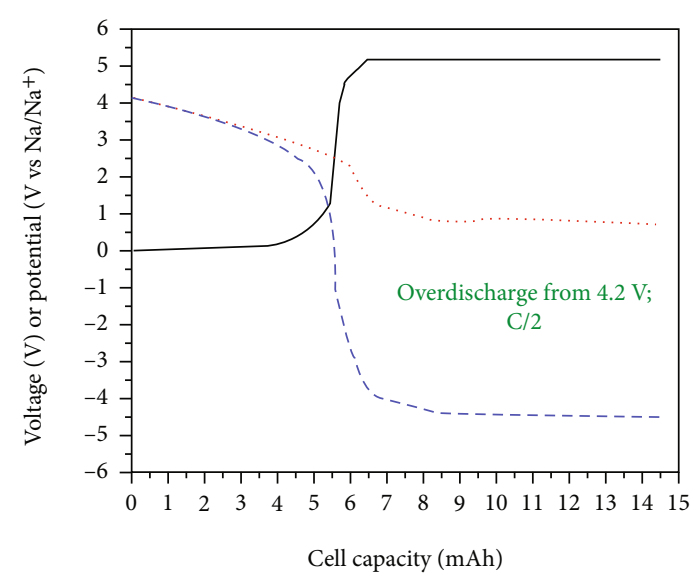

(a)

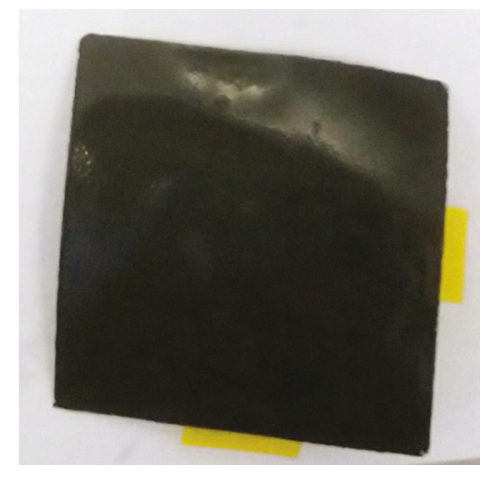

(b)

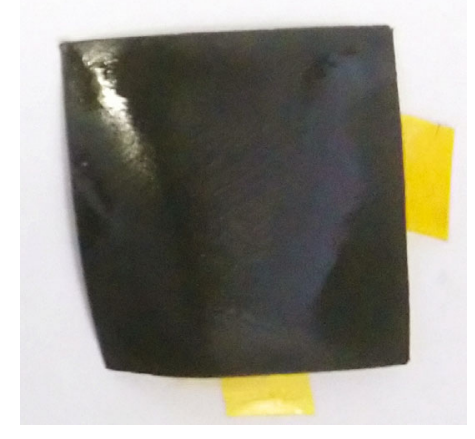

(c)

$$
\begin{array}{ll}
\text { - - - } & \text { Full cell voltage } \\
\ldots . . . & \text { Cathode potential } \\
\ldots & \text { Anode potential }
\end{array}
$$

FiguRE 6: Effect of overdischarging Na-ion cell down to negative voltages. (a) Cycling profile of a three-electrode Na-ion cell where the cell was made to discharge from $4.2 \mathrm{~V}$ to $\sim 2.5$ times its nominal capacity at $\mathrm{C} / 2$ rate at $30^{\circ} \mathrm{C}$. Optical pictures of the (b) anode and (c) cathode harvested from this cell after the overdischarge event showing no visible decomposition products despite not washing with any solvent.

durations below $0 \mathrm{~V}$ has deleterious effects on cell safety [14]. But in general, overdischarging Na-ion cells below $0 \mathrm{~V}$ should be avoided as much as possible. As an interesting aside, if a $\mathrm{Na}$-ion cell is appropriately capacity balanced and uses oxidatively stable electrolytes (such as an oxidative limit to $4.5 \mathrm{~V}$ vs. $\mathrm{Na} / \mathrm{Na}^{+}$), there is no reason why Na-ion cells cannot be cycled in a stable fashion from say $4.5 \mathrm{~V}$ to $-1.0 \mathrm{~V}$ or even lower, as long as the anode's potential stays under the oxidative stability limit of the electrolyte during discharge (it is another matter if it makes any practical sense to do so). This situation would apply to Li-ion cells as well: for example, by significantly increasing the N/P ratio, even graphite-based Li-ion cells can be discharged down to $0 \mathrm{~V}$ or beyond (as long as the anode potential stays below the $\mathrm{Cu}$ dissolution potentials), but this will noticeably reduce their energy density, perhaps even significantly, on account of the weight and volume penalties imposed by the excessive anode (this is the reason why this approach is not common for Li-ion cells). As an interesting corollary, it is anticipated that graphitebased Li-ion cells using alternate and more oxidatively stable current collectors, or indeed utilising freestanding graphite electrodes, might behave similarly to Na-ion cells on the issue of overdischarging to $0 \mathrm{~V}$ and beyond. However, this hypothesis would need to be proven.

From a practical viewpoint, it makes little sense to design a Na-ion cell or pack to go down to $0 \mathrm{~V}$ during its actual operation, as the low voltages will place undue burden on the associated power electronics in the battery pack. Thus, $\mathrm{Na}$-ion systems will be naturally designed to end their discharge at higher voltages, such as $1 \mathrm{~V}$ or $2 \mathrm{~V}$, which will also be dictated by the application's requirements. It follows that, during operation, the $1 \mathrm{~V}$ or $2 \mathrm{~V}$ limit can be the designed $0 \%$ SOC (as might occur for Li-ion cells), but unlike the Li-ion case, $\mathrm{Na}$-ion cells would also incorporate an inherent safety-factor of actually being able to be discharged to $0 \mathrm{~V}$ (for Li-ion, the $0 \%$ SOC is a hard limit keeping future cell performance in mind, as discussed in the prior sections). Therefore, the likelihood of a Na-ion cell to be overdischarged (experience negative voltages) in practical systems during operation, with a functioning BMS, would be much lower than the case for a Li-ion pack (with a functioning BMS) due to this inbuilt safety-factor for Na-ion systems. Of course, out of operation (such as during shipping or long-term storage), Na-ion systems can be designed to be discharged to $0 \mathrm{~V}$ with peace of mind. As another point, it can be appreciated that for a Na-ion cell kept at opencircuit conditions at a finite SOC for very long durations, self-discharge (whose rates we expect to be similar to those seen in Li-ion cells) would never drive a $\mathrm{Na}$-ion cell down to its overdischarge conditions: at worst, self-discharge would cause voltage decay up to $0 \mathrm{~V}$ and not beyond, as there will be no driving force to go further to negative voltages.

\section{Summary and Future Studies}

In this article, we have shone a spotlight on one particular aspect of Li-ion cells and compared it with that of its analogue, the Na-ion cell: the reasons behind the commonly used SOCs while shipping and storing such alkali-ion cells from their basic materials chemistry viewpoint. A review of the state of knowledge in the Li-ion field, summarized herein, reiterates that overdischarging graphite-based $\mathrm{Li}$ ion cells below their rated 0\% SOC (which might be 2$2.8 \mathrm{~V}$ ) can significantly reduce cycle life to mere tens of cycles (best case scenario) or potentially result in fires/explosions due to internal short-circuits instigated by metallic $\mathrm{Cu}$ plating on the cathode (worst case scenario). Conversely, it is inherently safe for a Na-ion cell to be discharged down to $0 \mathrm{~V}$. The use of Al current collector on the anode, as opposed to $\mathrm{Cu}$, is the fundamental reason why $\mathrm{Na}$-ion cells can be safely discharged to $0 \mathrm{~V}$ and is incidentally also beneficial 
in boosting a cell's specific energy and reducing costs as $\mathrm{Al}$ is much lighter and cheaper than $\mathrm{Cu}$. We further presented the first observations on overdischarging $\mathrm{Na}$-ion cells below $0 \mathrm{~V}$, to negative voltages: it was shown that no visible deposits were seen on the cathode or anode in the course of overdischarging Na-ion cells to $\sim 2.5$ times their rated capacities.

The $0 \mathrm{~V}$ capability of the Na-ion technology will benefit not just customers who will be using the end product but also Na-ion battery manufacturers who can capitalise on the $0 \mathrm{~V}$ capability of Na-ion cells in three ways. Firstly, during the shipping and transportation of commercial $\mathrm{Na}$-ion cells or even packs, a physical short can be actually placed between the positive and negative terminals of the Na-ion cell or pack, as shown in some of our prior publications or patent applications $[14,59,61,62]$. Secondly and perhaps not so obviously, this $0 \mathrm{~V}$ capability gives cell manufacturers flexibility in scheduling the time intervals between filling $\mathrm{Na}$-ion cells with electrolytes and placing them for formation cycling: in graphite-based Li-ion cells, the clock starts ticking as soon as Li-ion cells are filled, and they would need to be formed as soon as possible to avoid $\mathrm{Cu}$ dissolution. The $0 \mathrm{~V}$ capability of $\mathrm{Na}$-ion cells will thus give manufacturers plenty of logistical freedom; for example, the $\mathrm{Na}$-ion cells can be filled in one part of the world, stored for a while, and then shipped to another part of the world to undergo its formation cycling. Thirdly, another practical benefit for battery manufacturers is that the installation of $\mathrm{Na}$-ion battery packs by their engineers would be inherently safe as the shorted cells would be at a zero energy state-the risks during installation will be significantly lower than installation of a graphite-based Li-ion pack at 30\% SOC.

For any rechargeable alkali-ion cell, $0 \mathrm{~V}$ or zero energy will be the ultimate safety condition. As we have shown herein, $\mathrm{Na}$-ion cells can be safely discharged and stored at $0 \mathrm{~V}$ without any safety concerns. Suggestions for future studies which further investigate some aspects around the $0 \mathrm{~V}$ capability of different types of Na-ion cells, are outlined below:

(1) It has already been demonstrated that different types of Na-ion cells exhibit exemplary levels of safety even at $100 \%$ SOC $[14,18,63,64]$. But the effect of overdischarging Na-ion cells below $0 \mathrm{~V}$ (relevant only during cycling of failed $\mathrm{Na}$-ion cells/packs) is poorly understood at this stage. The initial forays reported herein are just the starting point-significant efforts need to be undertaken to understand how continued overdischarge will affect Na-ion cells, especially in large-scale cells

(2) In conducting the above studies, particular emphasis should be put on the effect of the electrolyte as it is known that there is an intimate relationship between the safety of a Li-ion cell and the electrolyte it contains $[6,12]$. Some recent results on large-scale $\mathrm{Na}$-ion cells indicate that $\mathrm{Na}$-ion electrolytes utilising high weight fractions of thermally stable solvents such as PC or Tetraglyme can indeed result in lower rates of heat generation or higher thresholds for onset of exothermic self-heating reactions [65-68]
(3) Recently, some articles have analysed the economic potential of $\mathrm{Na}$-ion batteries from a materials perspective [19-21]. Detailed life-cycle cost estimations for Na-ion batteries, focussing on not just material costs or resource availability, but other factors such as costs of shipping/storing $\mathrm{Na}$-ion cells at $0 \mathrm{~V}$, relative to Li-ion cells at 30\% SOC, and also their recycling, would certainly be timely and illuminating for the alkali-ion battery community

\section{Conflicts of Interest}

The authors declare that there is no conflict of interest regarding the publication of this article.

\section{Acknowledgments}

The authors thank Faradion Limited for permission to publish this article and Faradion staff in helping achieve the results contained herein.

\section{References}

[1] "Faraday Report - January 2020. High-Energy Battery Technologies," (accessed April 14, 2021), https://faraday.ac.uk/ wp-content/uploads/2020/01/High-Energy-batterytechnologies-FINAL.pdf.

[2] T. Alsop, "Forecast: global shipment of tablets, laptops and desktop PCs 2010-2024," 2021, (accessed April 14, 2021), https://www.statista.com/statistics/272595/global-shipmentsforecast-for-tablets-laptops-and-desktop-pcs/.

[3] M. Chau and R. Reith, "Smartphone market share," 2021, (accessed April 14, 2021), https://www.idc.com/promo/ smartphone-market-share/vendor.

[4] L. Bravo Diaz, X. He, Z. Hu et al., "Review-meta-review of fire safety of lithium-ion batteries: industry challenges and research contributions," Journal of The Electrochemical Society, vol. 167, no. 9, article 090559, 2020.

[5] D. H. Doughty and E. P. Routh, "A general discussion of Li ion battery safety," Electrochemical Society Interface, vol. 21, pp. 37-44, 2012.

[6] K. Liu, Y. Liu, D. Lin, A. Pei, and Y. Cui, "Materials for lithium-ion battery safety," Science Advances, vol. 4, no. 6, article eaas9820, 2018.

[7] “2021 Lithium Battery Guidance Document,” 2020, (accessed April 14, 2021), https://www.iata.org/contentassets/ 05e6d8742b0047259bf3a700bc9d42b9/lithium-batteryguidance-document-2021.pdf.

[8] H. Huo, Y. Xing, M. Pecht, B. J. Züger, N. Khare, and A. Vezzini, "Safety requirements for transportation of lithium batteries," Energies, vol. 10, no. 6, p. 793, 2017.

[9] M. Ottaviani, "Lithium batteries transport and packaging instructions," (accessed April 14, 2021), https://lithium .batteriestransport.org/.

[10] Y. E. Durmus, H. Zhang, F. Baakes et al., "Side by side battery technologies with lithium-ion based batteries," Advanced Energy Materials, vol. 10, no. 24, article 2000089, 2020.

[11] J.-M. Tarascon, "Na-ion versus Li-ion batteries: complementarity rather than competitiveness," Joule, vol. 4, no. 8, pp. 1616-1620, 2020. 
[12] Q. Wang, L. Jiang, Y. Yu, and J. Sun, "Progress of enhancing the safety of lithium ion battery from the electrolyte aspect," Nano Energy, vol. 55, pp. 93-114, 2019.

[13] Datasheet, "Toshiba Rechargeable Battery SCiB High Power 2.9 Ah Cell," (accessed April 15, 2021), https://www.global .toshiba/content/dam/toshiba/ww/products-solutions/ battery/scib/pdf/ToshibaRechargeableBattery-en.pdf.

[14] A. Rudola, A. J. R. Rennie, R. Heap et al., "Commercialisation of high energy density sodium-ion batteries: Faradion's journey and outlook," Journal of Materials Chemistry A, vol. 9, no. 13, pp. 8279-8302, 2021.

[15] N. Yabuuchi, K. Kubota, M. Dahbi, and S. Komaba, "Research Development on Sodium-Ion Batteries," Chemical Reviews, vol. 114, no. 23, pp. 11636-11682, 2014.

[16] J.-Y. Hwang, S.-T. Myung, and Y.-K. Sun, "Sodium-ion batteries: present and future," Chemical Society Reviews, vol. 46, no. 12, pp. 3529-3614, 2017.

[17] H. Pan, Y.-S. Hu, and L. Chen, "Room-temperature stationary sodium-ion batteries for large-scale electric energy storage," Energy \& Environmental Science, vol. 6, no. 8, pp. 23382360, 2013.

[18] A. Bauer, J. Song, S. Vail, W. Pan, J. Barker, and Y. Lu, “The scale-up and commercialization of nonaqueous Na-ion battery technologies," Advanced Energy Materials, vol. 8, no. 17, article 1702869, 2018.

[19] D. Karabelli, S. Singh, S. Kiemel et al., "Sodium-based batteries: in search of the best compromise between sustainability and maximization of electric performance," Frontiers in Energy Research, vol. 8, 2020.

[20] J. F. Peters, A. Peña Cruz, and M. Weil, "Exploring the economic potential of sodium-ion batteries," Batteries, vol. 5, no. 1, p. 10, 2019.

[21] C. Vaalma, D. Buchholz, M. Weil, and S. Passerini, "A cost and resource analysis of sodium-ion batteries," Nature Reviews Materials, vol. 3, no. 4, article 18013, 2018.

[22] R. Rupp, B. Caerts, A. Vantomme, J. Fransaer, and A. Vlad, "Lithium Diffusion in Copper," The Journal of Physical Chemistry Letters, vol. 10, no. 17, pp. 5206-5210, 2019.

[23] C. Mikolajczak, M. Kahn, K. White, and R. T. Long, Lithiumion Batteries Hazard and Use Assessment, Springer Science \& Business Media, 2012.

[24] M. J. Lain, J. Brandon, and E. Kendrick, "Design strategies for high power vs. high energy lithium ion cells," Batteries, vol. 5, no. 4, p. 64, 2019.

[25] H. Popp, N. Zhang, M. Jahn et al., “Ante-mortem analysis, electrical, thermal, and ageing testing of state-of-the-art cylindrical lithium-ion cells," e \& $i$ Elektrotechnik und Informationstechnik, vol. 137, no. 4-5, pp. 169-176, 2020.

[26] P. Arora, R. E. White, and M. Doyle, "Capacity fade mechanisms and side reactions in lithium-ion batteries," Journal of the Electrochemical Society, vol. 145, no. 10, pp. 3647-3667, 1998.

[27] L. Lu, X. Han, J. Li, J. Hua, and M. Ouyang, "A review on the key issues for lithium-ion battery management in electric vehicles," Journal of Power Sources, vol. 226, pp. 272-288, 2013.

[28] T. Langner, T. Sieber, and J. Acker, "Studies on the deposition of copper in lithium-ion batteries during the deep discharge process," Scientific Reports, vol. 11, no. 1, p. 6316, 2021.

[29] J. Kasnatscheew, M. Börner, B. Streipert et al., "Lithium ion battery cells under abusive discharge conditions: electrode potential development and interactions between positive and negative electrode," Journal of Power Sources, vol. 362, pp. 278-282, 2017.

[30] H. He, Y. Liu, Q. Liu et al., "Failure investigation of $\mathrm{LiFePO}_{4}$ Cells in over-discharge conditions," Journal of the Electrochemical Society, vol. 160, no. 6, pp. A793-A804, 2013.

[31] M. Flügel, M. Kasper, C. Pfeifer, M. Wohlfahrt-Mehrens, and T. Waldmann, "Cu dissolution during over-discharge of Liion cells to $0 \mathrm{~V}$ : a post-mortem study," Journal of the Electrochemical Society, vol. 168, no. 2, article 020506, 2021.

[32] C. E. Hendricks, A. N. Mansour, D. A. Fuentevilla, G. H. Waller, J. K. Ko, and M. G. Pecht, "Copper dissolution in overdischarged lithium-ion cells: X-ray photoelectron spectroscopy and X-ray absorption fine structure analysis," Journal of the Electrochemical Society, vol. 167, article 090501, 2020.

[33] M. Flügel, T. Waldmann, M. Kasper, and M. WohlfahrtMehrens, "Detection of copper deposition on anodes of over-discharged lithium ion cells by GD-OES depth profiling," ChemPhysChem, vol. 21, no. 18, pp. 2047-2050, 2020.

[34] T. Ma, S. Wu, F. Wang et al., "Degradation mechanism study and safety hazard analysis of overdischarge on commercialized lithium-ion batteries," ACS Applied Materials \& Interfaces, vol. 12, no. 50, pp. 56086-56094, 2020.

[35] C. Fear, D. Juarez-Robles, J. A. Jeevarajan, and P. P. Mukherjee, "Elucidating copper dissolution phenomenon in Li-ion cells under overdischarge extremes," Journal of the Electrochemical Society, vol. 165, no. 9, pp. A1639-A1647, 2018.

[36] H. Maleki and J. N. Howard, "Effects of overdischarge on performance and thermal stability of a Li-ion cell," Journal of Power Sources, vol. 160, no. 2, pp. 1395-1402, 2006.

[37] L. Rui, W. Lizhi, H. Xueli, D. Qiang, and Z. Jie, "A review of equalization topologies for lithium-ion battery packs," in 2015 34th Chinese Control Conference (CCC), pp. 79227927, Hangzhou, China, 2015.

[38] L. Yuang-Shung and C. Ming-Wang, "Intelligent control battery equalization for series connected lithium-ion battery strings," IEEE Transactions on Industrial Electronics, vol. 52, pp. 1297-1307, 2005.

[39] L. Xie, D. Ren, L. Wang et al., "A facile approach to high precision detection of cell-to-cell variation for Li-ion batteries," Scientific Reports, vol. 10, no. 1, p. 7182, 2020.

[40] K. Rumpf, M. Naumann, and A. Jossen, "Experimental investigation of parametric cell-to-cell variation and correlation based on 1100 commercial lithium-ion cells," Journal of Energy Storage, vol. 14, pp. 224-243, 2017.

[41] Y. Preger, H. M. Barkholtz, A. Fresquez, D. L. Campbell, B. W. Juba, J. Romàn-Kustas et al., "Degradation of commercial lithium-ion cells as a function of chemistry and cycling conditions," Journal of the Electrochemical Society, vol. 167, article 120532, 2020.

[42] S. J. Harris, D. J. Harris, and C. Li, "Failure statistics for commercial lithium ion batteries: a study of 24 pouch cells," Journal of Power Sources, vol. 342, pp. 589-597, 2017.

[43] J. P. Rivera-Barrera, N. Muñoz-Galeano, and H. O. SarmientoMaldonado, "SoC estimation for lithium-ion batteries: review and future challenges," Electronics, vol. 6, no. 4, p. 102, 2017.

[44] J. Meng, M. Ricco, G. Luo et al., "An overview of online implementable SOC estimation methods for lithium-ion batteries," in 2017 International Conference on Optimization of Electrical and Electronic Equipment (OPTIM) \& 2017 Int Aegean Conference on Electrical Machines and Power Electronics (ACEMP), pp. 573-580, Brasov, Romania, 2017. 
[45] R. Zhang, B. Xia, B. Li et al., "State of the art of lithium-ion battery SOC estimation for electrical vehicles," Energies, vol. 11, no. 7, p. 1820, 2018.

[46] M. Ecker, N. Nieto, S. Käbitz et al., "Calendar and cycle life study of $\mathrm{Li}(\mathrm{NiMnCo}) \mathrm{O}_{2}$-based 18650 lithium-ion batteries," Journal of Power Sources, vol. 248, pp. 839-851, 2014.

[47] D. Linden and T. B. Reddy, Handbook of Batteries, McGrawHill, 3rd edition, 2002.

[48] E. Redondo-Iglesias, P. Venet, and S. Pelissier, "Global model for self-discharge and capacity fade in lithium-ion batteries based on the generalized Eyring relationship," IEEE Transactions on Vehicular Technology, vol. 67, no. 1, pp. 104-113, 2018.

[49] W. M. Seong, K.-Y. Park, M. H. Lee et al., "Abnormal selfdischarge in lithium-ion batteries," Energy \& Environmental Science, vol. 11, no. 4, pp. 970-978, 2018.

[50] J. P. Schmidt, A. Weber, and E. Ivers-Tiffée, "A novel and fast method of characterizing the self-discharge behavior of lithium-ion cells using a pulse-measurement technique," Journal of Power Sources, vol. 274, pp. 1231-1238, 2015.

[51] A. H. Zimmerman, "Self-discharge losses in lithium-ion cells," IEEE Aerospace and Electronic Systems Magazine, vol. 19, no. 2, pp. 19-24, 2004.

[52] Brochure, "KOKAM Li-ion/polymer cell," (accessed April 29, 2021), https://kokam.com/wp-content/uploads/2016/03/ SLPB-Cell-Brochure.pdf.

[53] "Datasheet: SLPB 283452H," (accessed April 29, 2021), https:// www.custompower.com/documents/SLB283452H.pdf.

[54] D. Fuentevilla, C. Hendricks, and A. Mansour, "Quantifying the impact of overdischarge on large format lithium-ion cells," ECS Transactions, vol. 69, no. 20, pp. 1-4, 2015.

[55] M. Börner, A. Friesen, M. Grützke et al., "Correlation of aging and thermal stability of commercial 18650-type lithium ion batteries," Journal of Power Sources, vol. 342, pp. 382-392, 2017.

[56] P. Ribière, S. Grugeon, M. Morcrette, S. Boyanov, S. Laruelle, and G. Marlair, "Investigation on the fire-induced hazards of Li-ion battery cells by fire calorimetry," Energy \& Environmental Science, vol. 5, no. 1, pp. 5271-5280, 2012.

[57] H. Biteau and N. Nava, "Transportation of Li-ion batteries: the state of charge parameter," 2017, (accessed April 20, 2021), https://www.nfpa.org/News-and-Research/Data-researchand-tools/Proceedings/SUPDET-AUBE.

[58] J. L. Murray, “The Al-Na (aluminum-sodium) system,” Bulletin of Alloy Phase Diagrams, vol. 4, no. 4, pp. 407-410, 1983.

[59] A. Rudola, F. Coowar, R. Heap, and J. Barker, "The Design, Performance and Commercialization of Faradion's Nonaqueous Na-ion Battery Technology," in Na-ion Batteries, L. Monconduit and L. Croguennec, Eds., ISTE \& John Wiley and Sons, London, New York, 2021.

[60] G. G. Eshetu, G. A. Elia, M. Armand et al., "Electrolytes and interphases in sodium-based rechargeable batteries: recent advances and perspectives," Advanced Energy Materials, vol. 10, no. 20, article 2000093, 2020.

[61] J. Barker and C. J. Wright, "Storage and/or transportation of sodium-ion cells,” US Patent 20170237270, 2017.

[62] J. Barker and C. J. Wright, "Storage and/or transport of sodium ion batteries," China Patent CN107078350, 2020.

[63] Y. Li, Y. Lu, L. Chen, and Y.-S. Hu, "Failure analysis with a focus on thermal aspect towards developing safer $\mathrm{Na}$-ion batteries," Chinese Physics B, vol. 29, no. 4, article 048201, 2020.
[64] Y. Li, Y.-S. Hu, X. Qi et al., “Advanced sodium-ion batteries using superior low cost pyrolyzed anthracite anode: towards practical applications," Energy Storage Materials, vol. 5, pp. 191-197, 2016.

[65] L. U. Subasinghe, G. Satyanarayana Reddy, A. Rudola, and P. Balaya, "Analysis of heat generation and impedance characteristics of Prussian blue analogue cathode-based 18650-type sodium-ion cells," Journal of the Electrochemical Society, vol. 167, no. 11, article 110504, 2020.

[66] K. du, C. Wang, L. U. Subasinghe et al., "A comprehensive study on the electrolyte, anode and cathode for developing commercial type non-flammable sodium-ion battery," Energy Storage Materials, vol. 29, pp. 287-299, 2020.

[67] Y. Xie, G.-L. Xu, H. Che et al., "Probing thermal and chemical stability of $\mathrm{Na}_{x} \mathrm{Ni}_{1 / 3} \mathrm{Fe}_{1 / 3} \mathrm{Mn}_{1 / 3} \mathrm{O}_{2}$ Cathode material toward safe sodium-ion batteries," Chemistry of Materials, vol. 30, no. 15, pp. 4909-4918, 2018.

[68] K. Du, A. Rudola, and P. Balaya, "Investigations of thermal stability and solid electrolyte interphase on $\mathrm{Na}_{2} \mathrm{Ti}_{3} \mathrm{O}_{7} / \mathrm{C}$ as a non-carbonaceous anode material for sodium storage using non-flammable ether-based electrolyte," ACS Applied Materials \& Interfaces, vol. 13, no. 10, pp. 11732-11740, 2021. 